\title{
Efektivitas Fermentasi Susu Kambing Menggunakan Bakteri Lactobacillus rhamnosus dengan Penambahan Jus Buah Bit (Beta vulgaris L.) dalam Menghambat Pertumbuhan Bakteri Patogen Usus \\ ( The Effectiveness Fermentation of Goat's Milk Using Lactobacillus rhamnosus Bacteria with Addition of Beetroot Juice (Beta vulgaris L.) In Inhibiting The Growth of Intestinal Pathogenic Bacteria)
}

\author{
Linda Yanti Hutasuhut ${ }^{1}$, Zuraida Hanum ${ }^{1 *}$, Yurliasni $^{1}$ \\ ${ }^{1}$ Program Studi Peternakan, Fakultas Pertanian, Universitas Syiah Kuala \\ *Corresponding author: idazuraida@gmail.com
}

\begin{abstract}
Abstrak. Bit merupakan tanaman berbentuk akar mirip umbi-umbian. Bit sangat bermanfaat untuk dijadikan sebagai tambahan dalam bahan pangan karena mengandung antioksidan tinggi, vitamin $\mathrm{C}$ yang tinggi serta memiliki senyawa antibakteri yang mampu menghambat aktivitas pertumbuhan bakteri gram positif dan bakteri gram negatif. Tujuan penelitian ini untuk mengetahui efektivitas kemampuan susu kambing fermentasi menggunakan L. rhamnosus dan penambahan jus bit dalam menghambat pertumbuhan bakteri patogen usus. Penelitian ini menggunakan Rancangan Acak Lengkap (RAL) yang terdiri atas 5 (lima) perlakuan yaitu P0 = Kontrol, $\mathrm{P} 1=2 \%$ jus bit, $\mathrm{P} 2=4 \%$ jus bit, $\mathrm{P} 3=6 \%$ jus bit, dan $\mathrm{P} 4=8 \%$ jus bit dengan 4 (empat) kali ulangan. Data yang diperoleh dianalisis menggunakan ANOVA (Analysis of Variance), jika terdapat perbedaan yang nyata maka dilanjutkan dengan uji jarak berganda Duncan. Hasil penelitian menunjukan bahwa penambahan jus bit dengan persentase berbeda pada susu kambing fermentasi tidak berpengaruh nyata $(\mathrm{P}>0,05)$ terhadap kemampuan susu fermentasi untuk menghambat pertumbuhan bakteri Salmonella typhi namun berpengaruh sangat nyata $(\mathrm{P}<0,01)$ terhadap kemampuan susu fermentasi untuk menghambat pertumbuhan bakteri Escherichia coli.
\end{abstract}

Kata kunci: Susu kambing fermentasi, Lactobacillus rhamnosus , jus bit, Escherichia coli, Salmonella typhi

\begin{abstract}
Beetroot is a root-shaped plant similar to tubers. Beetroot is very useful to be used as an addition in food ingredients because of its content such as high antioxidants, high vitamin $\mathrm{C}$ and has antibacterial compounds that are able to inhibit the growth activity of gram-positive bacteria and gram-negative bacteria. The purpose of this study is to find out the effectiveness of fermented goat milk capabilities using L. rhamnosus and the addition of beet juice in inhibiting the growth of pathogenic gut bacteria. This study used a Complete Randomized Design (RAL) consisting of 5 (five) treatments namely P0 $=$ Control, P1 $=2 \%$ beet juice, P2 $=4 \%$ beet juice, $\mathrm{P} 3=6 \%$ beet juice, and $\mathrm{P} 4=8 \%$ beet juice with 4 (four) times the replay. The data obtained was analyzed using ANOVA (Analysis of Variance), if there are noticeable differences then continued with Duncan's multiple distance test. The results showed that the addition of beet juice with a different percentage in fermented goat milk had no real effect $(\mathrm{P}>0.05)$ on the ability of fermented milk to inhibit the growth of Salmonella typhi bacteria but had a very real effect $(\mathrm{P}<0.01)$ on the ability of fermented milk to inhibit the growth of Escherichia coli bacteria.
\end{abstract}

Keywords: Fermented goat's milk, Lactobacillus rhamnosus, beet juice, Escherichia coli, Salmonella typhi

\section{PENDAHULUAN}

Gangguan pencernaan merupakan salah satu masalah kesehatan yang masih banyak ditemui di kalangan masyarakat. Berdasarkan data WHO (World Health Organization) pada tahun 2012 dilaporkan bahwa jumlah orang yang meninggal dunia akibat penyakit saluran pencernaan mencapai sekitar 1,5 juta. Salah satu penyebabnya adalah diare (WHO, 2014). Penularan penyakit ini dapat berasal dari makanan atau minuman yang telah terkontaminasi 
oleh bakteri patogen sehingga jika dikonsumsi dapat meningkatkan populasi bakteri patogen di dalam saluran pencernaan (Sanjaya et al., 2013).

Escherichia coli merupakan salah satu bakteri yang secara normal terdapat di dalam saluran pencernaan manusia. Namun apabila peningkatan jumlah bakteri E. coli terjadi pada saluran pencernaan maka bakteri ini akan menghasilkan senyawa enterotoksin yang menyebabkan terjadinya beberapa infeksi yang berasosiasi dengan enteropatogenik yang menghasilkan enterotoksin pada sel epitel (Ismail, 2012). Senyawa enterotoksin yang dihasilkan di luar usus merupakan penyebab terjadinya diare (Brooks et al., 2004). Selain E. coli, bakteri Salmonella typhimurium juga merupakan bakteri patogen penyebab gastroenteritis pada manusia (Pelczar et al., 2005). Salmonella dapat menginfeksi jaringan pada usus, memproduksi enterotoksin, menyebabkan inflamasi dan diare. Apabila bakteri ini sampai menginfeksi saluran darah dan limfa, maka penyakit yang ditimbulkan dapat berakibat lebih fatal (Bell et al., 2002).

Pemanfaatan susu fermentasi dan produk sejenisnya merupakan alternatif yang telah banyak dikembangkan untuk mengatasi masalah pencernaan. susu fermentasi merupakan sebuah media yang tepat sebagai pembawa bakteri probiotik. Bakteri probiotik memiliki sifat sebagai antimikroba sehingga mampu menekan pertumbuhan bakteri patogen di dalam saluran pencernaan. Mikroorganisme yang umumnya digunakan sebagai bakteri probiotik terutama bakteri asam laktat dari genus Lactobacillus dan Bifidobacterium. Salah satunya adalah bakteri Lactobacillus rhamnosus.

Lactobacillus rhamnosus merupakan bakteri asam laktat (BAL) yang memiliki potensi sebagai probiotik. Isolat tersebut memiliki ketahanan yang baik pada kondisi saluran pencernaan seperti $\mathrm{pH}$ rendah $(\mathrm{pH} \mathrm{2,3}$ dan 4) dan empedu (deoksikolat), mampu melewati kondisi usus dengan kandungan 0,4 mM sodium deoksikolat dan pankreatin (Uni, 2012). L. rhamnosus yang diisolasi dari air susu ibu secara in vitro memiliki daya hambat yang besar terhadap Bacillus cereus, Escherechia coli, Salmonella typhimurium dan Staphylococcus aureus (Hartanti dan Nuraida, 2007).

Pemanfaatan berbagai jenis tanaman dan buah-buahan sebagai bahan campuran dalam produk susu fermentasi sudah banyak digunakan, seperti penambahan sari buah bit merah (Susanto et al., 2014). Buah bit (Beta vulgaris L.) merupakan tanaman berbentuk akar mirip umbi-umbian yang mengandung vitamin $\mathrm{C}$ cukup tinggi. Komponen utama buah bit berupa pigmen betasianin yang memberikan warna merah keunguan dan diketahui memiliki efek radikal dan aktivitas antioksidan tinggi (Wibawanto, 2014). Disamping itu, buah bit juga diketahui mempunyai aktivitas antibakteri karena mengandung beberapa senyawa yang mampu menghambat aktivitas bakteri gram positif dan bakteri gram negatif seperti Escherichia coli (Canadanovic-Brunet et al., 2011).

Oleh sebab itu, perlu dikaji lebih lanjut tingkat efektivitas penghambatan susu kambing fermentasi menggunakan bakteri L. rhamnosus yang ditambahkan jus buah bit terhadap bakteri patogen usus Escherichia coli dan Salmonella typhimurium.

\section{METODE PENELITIAN}

Penelitian ini dilaksanakan di Laboratorium Ilmu dan Teknologi Pengolahan Susu Jurusan Peternakan Fakultas Pertanian Universitas Syiah Kuala, Banda Aceh pada Maret 2020 hingga Februari 2021. 


\section{MATERI DAN METODE}

\section{Alat dan Bahan}

Bahan yang digunakan pada penelitian ini adalah susu kambing yang berasal dari UD. Abi Makmur Sentosa, bakteri Lactobacillus rhamnnosus yang diperoleh dari PAU UGM, buah bit yang diperoleh dari Pasar Aceh, serta bakteri Salmonella typhimurium C050 dan bakteri Escherichia coli FNCC 0091 koleksi dari Laboratorium Ilmu dan Teknologi Pengolahan Susu.

Alat-alat yang digunakan adalah laminar flow, autoklaf, inkubator, timbangan digital, colony counter, waterbath, vortex, hotplate, botol sampel $250 \mathrm{ml}$, erlenmayer $500 \mathrm{ml}$, beaker glass $1000 \mathrm{ml}$, beaker glass $500 \mathrm{ml}$, gelas ukur $500 \mathrm{ml}$, cawan petri (CMSI), mikropipet, lampu spiritus, rak tabung reaksi, tabung reaksi, penggaris, pinset, pisau, dan spatula.

\section{Susu Kambing Fermentasi}

Susu kambing segar dipasteurisasi ke dalam waterbath dengan suhu $85^{\circ} \mathrm{C}$ selama 15 detik, lalu didinginkan sampai suhu $40^{\circ} \mathrm{C}$. Kemudian jus bit ditimbang sebanyak 250 gram lalu dicuci dengan air mengalir dan dikupas kulitnya. Bit dipotong menjadi beberapa bagian dan dihaluskan menggunakan juicer lalu disaring menggunakan kain saring. Setelah itu, jus bit yang diperoleh dipasteurisasi pada suhu $75^{\circ} \mathrm{C}$ selama 15 detik (Litbang Pertanian, 2017). Kemudian susu yang telah dipasteurisasi dimasukkan ke dalam 5 (lima) botol sampel berukuran $250 \mathrm{ml}$ dan ditambahkan $5 \%$ bakteri starter Lactobacillus rhamnosus dan jus bit dengan persentase sesuai dengan perlakuan $(0 \%, 2 \%, 4 \%, 6 \%, 8 \%)$ lalu dihomogenkan secara merata. Setiap perlakuan memiliki volume yang sama $250 \mathrm{ml}$ dan dilakukan sebanyak 4 (empat) kali ulangan. Selanjutnya, sampel diinkubasi pada suhu $37^{\circ} \mathrm{C}$ selama $24 \mathrm{jam}$, dan dilakukan analisa.

\section{Rancangan Penelitian}

Penelitian ini menggunakan rancangan acak lengkap (RAL) yang terdiri 5 (lima) pelakuan, yaitu $\mathrm{P}_{0}=0 \%$ jus bit (kontrol), $\mathrm{P}_{1}=2 \%$ jus bit, $\mathrm{P}_{2}=4 \%$ jus bit, $\mathrm{P}_{3}=6 \%, \mathrm{P}_{4}=8 \%$ jus bit, setiap perlakuan diulang sebanyak 4 kali sehingga terdapat 20 unit percobaan dengan penambahan $5 \%$ bakteri L. rhamnosus pada masing-masing botol sampel.

\section{Uji Daya Hambat terhadap Escherichia coli}

Uji daya hambat dilakukan menggunakan metode kertas cakram. Uji daya hambat dilakukan dengan cara diambil 1 ose bakteri Escherichia coli menggunakan jarum ose, kemudian dimasukkan ke dalam tabung reaksi yang sudah berisi akuades sebanyak $9 \mathrm{ml}$, dilakukan pengenceran $10^{-1}$ sampai $10^{-3}$. Diinokulasikan $1 \mathrm{ml}$ suspensi dari pengenceran $10^{-3}$ ke dalam cawan petri yang telah berisi Nutrient Agar (NA), lalu dibiarkan beberapa saat agar media mengeras. Selanjutnya direndam kertas cakram ke dalam sampel pada setiap perlakuan selama 15 menit. Kertas cakram yang telah direndam diletakkan pada permukaan agar menggunakan pinset steril. Kemudian diinkubasi pada suhu $37^{\circ} \mathrm{C}$ selama 24 jam. Selanjutnya dilakukan pengukuran terhadap luas zona bening yang terbentuk (Agusmansyah, 2017).

\section{Uji Daya Hambat terhadap Salmonella typhi}

Uji daya hambat terhadap bakteri Salmonella typhi menggunakan metode kertas cakram. Diambil 1 ose bakteri Salmonella typhi menggunakan jarum ose, kemudian dimasukkan ke dalam tabung reaksi yang sudah berisi akuades sebanyak 9 ml, dilakukan pengenceran $10^{-1}$ sampai $10^{-3}$. Diinokulasikan $1 \mathrm{ml}$ suspense dari pengenceran $10^{-3} \mathrm{ke}$ dalam cawan petri yang telah berisi Nutrient Agar (NA), lalu dibiarkan beberapa saat agar media 
mengeras. Selanjutnya direndam kertas cakram ke dalam sampel pada setiap perlakuan selama 15 menit. Kertas cakram yang telah direndam diletakkan pada permukaan agar menggunakan pinset steril lalu diinkubasi pada suhu $37^{\circ} \mathrm{C}$ selama 24 jam. Selanjutnya dilakukan pengukuran tehadap luas zona bening yang terbentuk (Agusmansyah, 2017).

\section{Analisa Statistik}

Data yang diperoleh dianalisis menggunakan analisis sidik ragam (analysis of variance/ANOVA) dan jika terdapat perbedaan yang nyata dilanjutkan dengan uji jarak berganda Duncan (Duncan Multiple Range Test/DMRT) (Steel dan Torrie, 1995).

\section{HASIL DAN PEMBAHASAN}

\section{Daya Hambat Susu Fermentasi Terhadap Salmonella typhi}

Hasil pengamatan yang telah dilakukan, tidak ditemukannya zona hambat yang terbentuk oleh penambahan jus bit (Beta vulgaris L.) pada susu kambing fermentasi terhadap bakteri Salmonella typhi seperti yang ditunjukkan pada Gambar 2.
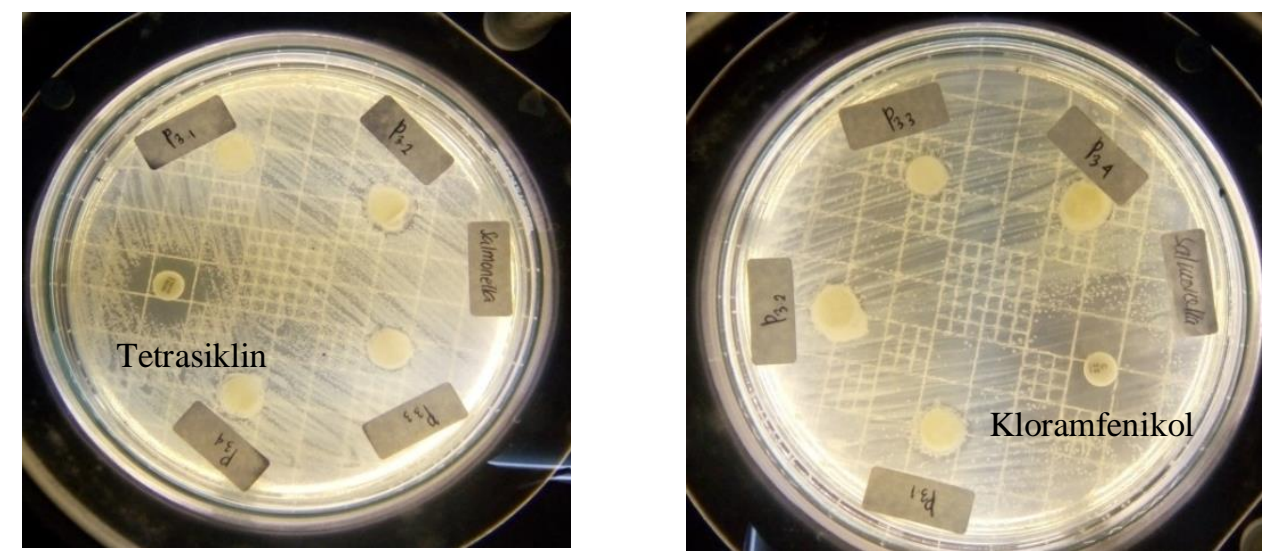

Gambar 1. Zona Hambat Susu Kambing Fermentasi Menggunakan Lactobacillus rhamnosus dengan Penambahan Persentase Jus Bit (Beta vulgaris L.) Berbeda Terhadap Salmonella typhi

(Sumber: Dokumentasi Penelitian, 2021)

Penambahan jus bit ke dalam susu fermentasi tidak mampu menghambat pertumbuhan bakteri Salmonella typhi. Zona bening yang terbentuk hanya terlihat pada kontrol antibiotik kloramfenikol dan tetrasiklin dengan diameter rata-rata pada masing-masing antibiotik sebesar 7,6 mm dan 22,4 mm. Kedua jenis antibiotik tersebut memiliki tingkat daya hambat yang kuat terhadap bakteri Salmonella typhi. Besarnya zona bening yang terbentuk dikarenakan kontrol antibiotika tetrasiklin dan kloramfenikol merupakan antibiotik berspektrum luas sehingga dapat bekerja dengan baik pada bakteri gram positif maupun bakteri gram negatif (Talaro, 2008).

Tidak adanya zona hambat yang terbentuk disebabkan bakteri Salmonella typhi resisten terhadap senyawa antibakteri yang dihasilkan. Waluyo (2007) dalam penelitiannya menyatakan bahwa Salmonella typhi merupakan bakteri gram negatif dengan dinding sel yang sangat kuat sehingga resisten terhadap senyawa-senyawa bioaktif yang dihasilkan dari susu fermentasi. Brooks et al., (2008) menyatakan membran luar dinding sel Salmonella typhi 
mengandung lipoprotein, fosfolipid, dan lipopolisakarida. Kandungan lipid bersifat impermeable dan berfungsi untuk mencegah masuknya bahan-bahan kimia dari luar. Sehingga adanya sistem seleksi zat-zat asing pada lapisan lipopolisakarida menyebabkan senyawa antibakteri sulit untuk masuk ke dalam sel dan menemukan target untuk bekerja. Selain itu juga diduga bahwa penambahan jus bit ke dalam susu kambing sebelum difermentasi menyebabkan bakteri L. rhamnosus tidak dapat bermetabolisme secara optimal.

\section{Daya Hambat Susu Fermentasi Terhadap Escherichia coli}

Escherichia coli merupakan salah satu jenis bakteri gram negatif yang digunakan sebagai bakteri indikator sanitasi terhadap air, makanan dan minuman. Peningkatan populasi bakteri ini di dalam saluran cerna manusia akan menjadi bakteri patogen. Hasil analisis sidik ragam menunjukkan bahwa susu kambing fermentasi menggunakan L. rhamnosus dengan penambahan persentase jus bit (Beta vulgaris L.) yang berbeda berpengaruh sangat nyata $(\mathrm{P}<0,01)$ terhadap luas zona hambat yang terbentuk pada bakteri $E$. coli. Luas zona hambat dapat dilihat pada Gambar 3.

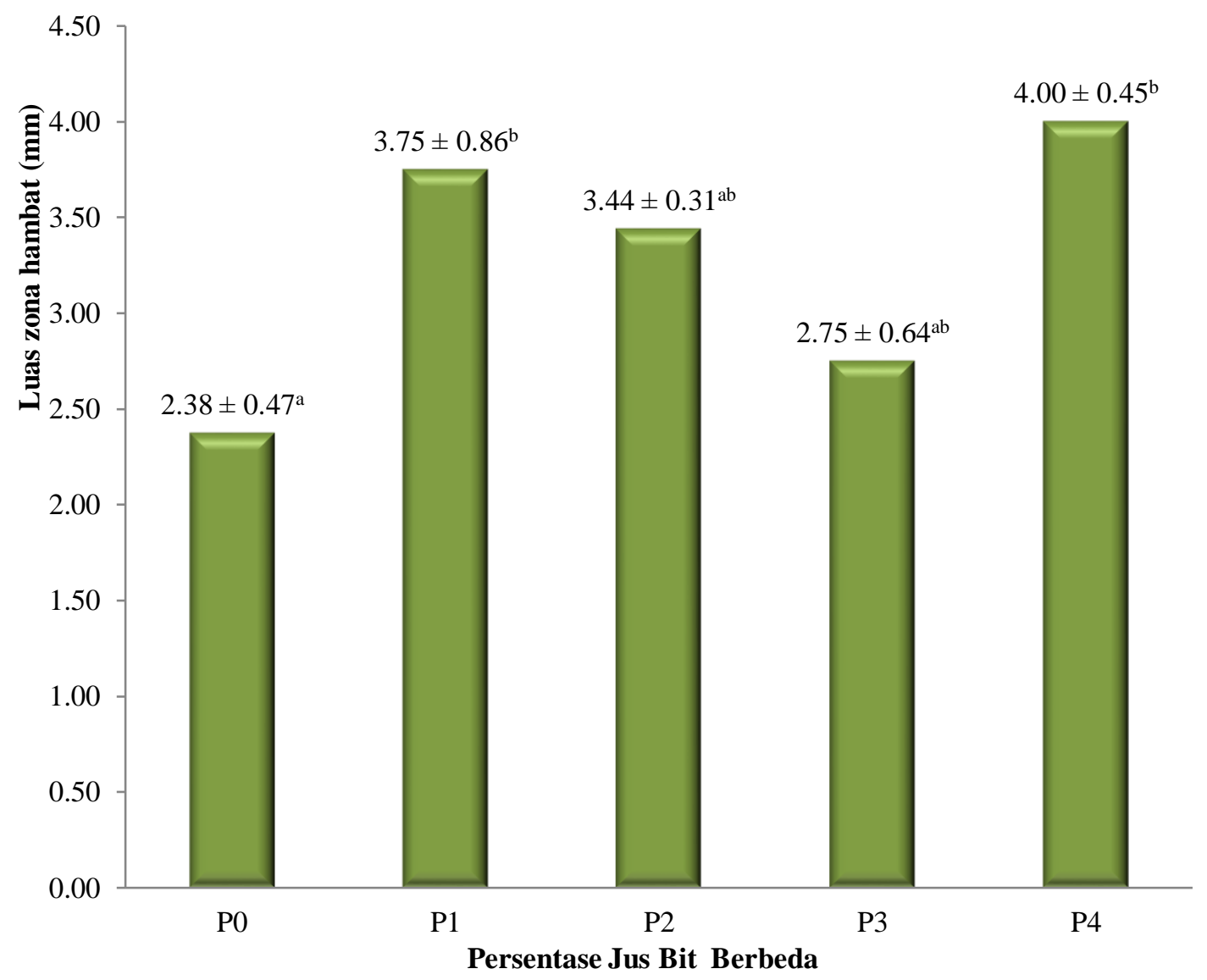

Keterangan : $\mathrm{P} 0=$ Kontrol; $\mathrm{P} 1=2 \%$ jus bit; $\mathrm{P} 2=4 \%$ jus bit; $\mathrm{P} 3=6 \%$ jus bit; $\mathrm{P} 4=8 \%$ jus bit

Gambar 2. Luas Daya Hambat Susu Kambing Fermentasi Menggunakan Lactobacillus rhamnosus dengan Penambahan Jus Bit (Beta vulgaris L.) dengan Persentase yang Berbeda Terhadap E. Coli 
Suryawiria (1978) menyatakan bahwa aktivitas antibakteri dapat digolongkan berdasarkan besarnya luas zona hambat yang terbentuk, yaitu lemah $(<5 \mathrm{~mm})$, sedang $(5-10$ $\mathrm{mm})$, kuat $(10-20 \mathrm{~mm})$ dan sangat kuat $(>20 \mathrm{~mm})$. Zona hambat yang terbentuk pada masingmasing perlakuan menunjukkan bahwa penambahan jus bit ke dalam susu fermentasi memiliki potensi untuk menghambat pertumbuhan bakteri E. coli dengan kategori lemah $<5$ mm. Hal ini sesuai dengan penelitian Canadavonic-Brunet et al., (2011) dimana ekstrak bit merah diketahui berpotensi menghambat bakteri $E$. coli $(8,00 \mathrm{~mm})$ dengan konsentrasi hambat minimum (KHM) $1,5 \mathrm{mg} / \mathrm{ml}$.

Kemampuan daya hambat susu kambing fermentasi dengan penambahan jus bit yang lemah terhadap E. coli diduga karena $E$. coli merupakan bakteri gram negatif dengan susunan dinding sel yang tebal dan dilapisi oleh membran luar yang mengandung protein, fosfolipid, dan lipopolisakarida (Karlina et al., 2013). Dinding luar sel yang memiliki sifat permeabilitas tinggi menjadikan senyawa antibakteri tidak dapat masuk secara maksimal ke dalam sel bakteri mengakibatkan kurang optimalnya daya hambat antibakteri terhadap pertumbuhan E. coli (Widyasanti et al., 2015).

\section{KESIMPULAN DAN SARAN}

\section{Kesimpulan}

Penambahan jus buah bit dengan konsentrasi berbeda yang ditambahkan pada proses pembuatan susu kambing fermentasi tidak berpengaruh terhadap uji daya hambat terhadap bakteri Salmonella typhi. Konsentrasi jus buah bit $8 \%$ memiliki potensi untuk menghambat bakteri Escherichia coli dengan luas zona hambat terbaik $8 \%$ yaitu 4,00 mm. Kemampuan daya hambat yang dihasilkan tergolong lemah $(<5 \mathrm{~mm})$ sehingga kurang efektif untuk menghambat pertumbuhan bakteri patogen usus.

\section{Saran}

Perlu dilakukan penelitian lanjutan dalam meningkatkan persentase penambahan jus bit dan penggunaan bakteri patogen lain seperti Staphylococcus aureus. Disarankan menggunakan ekstrak bit dan mengganti prosedur kerja untuk menghasilkan kinerja bit lebih optimal.

\section{DAFTAR PUSTAKA}

Agusmansyah, S. 2017. Uji efektifitas pengaruh ekstrak etanol daun tua sirsak pertumbuhan bakteri Staphylococcus aureus. Skripsi. Universitas Lampung, Lampung.

Bell, C., dan A. Kyriakides. 2002. Salmonella. Dalam Blackburn dan Mc Clure (eds). Foodborne patogens: Hazard, risk analysis and control. Woodhead Publishing Ltd, Cambridge.

Brooks, G.F., Butel, J.S., Ornston, L.N. 2008. Jawetz, Melnick dan Adelberg Mikrobiologi Kedokteran (terjemahan). Buku Kedokteran EGC, Jakarta. 627-9. 
Brooks, G.F., J. S. Butel, and S. A. Morse. 2004. Jawetz, Melnick, dan Adelberg Mikrobiologi Kedokteran. $23^{\text {rd }}$ ed. McGraw-Hill Companies Inc, New York. 623-651.

Canadanovic-Brunet, M. J., S. S. Savatovic, S. G. Cetkovic, J. J. Vulic, M. S. Djilas, L. S. Markov, and D. D. Cvtkovic. 2011. Antioxidant and antimicrobial activities of beetroot pomace extract. Czech J. Food Sci. 29 (6): 575-585.

Hartanti, A. W. 2007. Seleksi Bakteri Asam Laktat yang Berpotensi sebagai Probiotik dari Isolat Air Susu Ibu. Skripsi. Departemen Ilmu dan Teknologi Pangan IPB. Bogor.

Ismail, D. 2012. Uji Bakteri Escherichia coli Pada Minuman Susu Kedelai Bermerek dan Tanpa merek di kota surakarta. Naskah publikasi, Fakultas Kedokteran. Universitas Muhammadiyah Surakarta.

Karlina CY, M. Ibrahim, G. Trimulyono. 2013. Aktivitas antibakteri ekstrak herba krokot (Potulaca oleracea L.) terhadap Staphylococcus aureus dan Escherichia coli. Lentera Bio. 2(1):87-93.

Litbang pertanian. 2017. Teknologi pengolahan dan pengemasan sari buah belimbing. http://jakarta.litbang.pertanian.go.id/ind/index.php/info-teknologi/44-belimbing/30teknologi-pengolahan-dan-pengemasan-sari-buah-belimbing.html. Diakses tanggal 19 Juni 2021.

Pelczar, M. J. dan Chan, E. C. S. 2005. Dasar-dasar Mikrobiologi 1. UI Press, Jakarta.

Ruhama, E., H. Chairunnisa, H. A. W. Lengkey. 2016. Pengaruh tingkat penggunaan bit (Beta vulgaris L.) terhadap toatal bakteri asam laktat, $\mathrm{pH}$ dan nilai kesukaan set yogurt. Jurnal Peternakan Universitas Padjadjaran.

Sanjaya, T. A., dan E. Apriliana. 2013. Deteksi Escherichia colipada jajanan cendol yang dijual di pasar tradisional kota Bandar Lampung. Medical Journal of Lampung University, Lampung. ISSN 2337-3776.

Steel, C. J. dan J.H. Torrie. 1995. Prinsip dan Prosedur Statistik. PT. Gramedia, Jakarta

Suryawiria, U. 1978. Mikroba Lingkungan. Ed. ke- 2. ITB, Bandung.

Susanto, Y., Ira, N., dan Netty, K. 2014. Pengaruh variasi proporsi sari bit merah dan susu UHT terhadap sifat fisikokimia, mikrobiologis dan sensoris yoghurt. Jurnal teknologi pangan dan gizi Universitas Katolik Widya Mandala, Surabaya. 13(1): 34-39.

Talaro KP. 2008.Foundation in Microbiology: Basic PrinciplesSixth Edition. Mc Graw Hill. New York.

Uni, I. A. S. M. 2012. Isolasi Bakteri Asam Laktat Penghidrolisis Garam Empedu dari Feses Bayi dan Uji Ketahanan Terhadap pH Rendah untuk Pengembangan Probiotik. Skripsi. Jurusan Biologi FMIPA UNUD, Denpasar.

Waluyo, L. 2007. Uji Antimikroba Fraksi Metanol dan Dietil Eter Daun Tanaman Kesum (Polygonum minus). Publikasi, Agripura.

WHO (World Health Organization). 2014. The Top 10 causes of death. World Health Organization. http://www.who.int/mediacentre/factsheets/fs310/en/\#. Diakses tanggal: 15 Juli 2020.

Wibawanto, N. R., K. A. Victoria, dan P. Rika. 2014. Produksi Serbuk Pewarna Alami Bit Merah (Beta vulgaris L.) dengan Metode Oven Drying. Universitas Katolik Soegija Pranata, Semarang.

Widyasanti A, Siti H, Dadan R. 2015. Aktivitas antibakteri ekstrak teh putih terhadap bakteri Gram positif dan negatif. Jurnal Penelitian Teh dan Kina. 18(1): 55- 60. 